\title{
Urban and Rural Militia Organizations in Syria's Less Governed Spaces
}

\section{by Carl Wege}

\section{(cc) $\mathrm{BY}$}

This work is licensed under a Creative Commons Attribution 3.0 License.

\begin{abstract}
This paper contends decline of Bashar al-Assad's governing authority and the concomitant accretion of increasingly complex militia organizations suggests a future of petty militia fiefdoms affecting an Islamic veneer ruling the Syrian space. Geography, including its human domain, sustains the qualitative patterns of militia development and interactions across Syria's rural and urban spaces and defines the geographic areas of dominance of these militia fiefdoms. The concurrence of severe drought, the Arab Spring, and the availability of social media ignited the Syrian rebellion in 2011. The rebellion itself ultimately became a militarized arena for conflict between outside powers as foreign fighter enhanced Salafi Jihadist Organizations displaced aspirational moderates to dominate the armed opposition to the Assad regime. The civil war ultimately became demarcated by hundreds of militias separated generally into a three sided contest between Iranian, al-Qaeda affiliated and Islamic State affiliated militias establishing petty fiefdoms while attempting to govern the Syrian space.
\end{abstract}

Keywords: Urban And Rural Militia Organizations In Syria’s Less Governed Spaces

\section{Introduction}

Syria's civil war can be viewed through many lenses. The shape of the Syrian civil war in one sense is a gauge of the contest between modernity and its antagonists. At another level the popular uprising against Syria's Alawite dictatorship anchored in Ba'athist ideology, even conceding Ba'athist Westernizing and secularizing pretentions, was a response to the democratic aspirations initially defining the Arab Spring.[1]The Assad government is frequently described as an "Alawite regime" but it is important to note that the dominance of the Alawite sect is less significant than the constellation of favored families and affiliates, often linked by marriage and including some Sunni's and other preferred family networks in the web of Assad's government. The core extended families include Bashar Assad's mother Anisa Makhluf (no longer living in Syria), his sister Bushra and the Shawkat family of her husband as well as the larger Makluf and Shalessh families. These families and some others generally but not exclusively Alawite ran Syria’s government like a mafia fiefdom.[2] Politically the democratic aspirations firstly driving the popular revolt against the Assad dynasty are now washed away by a tide of Islamist and ethnic politics that is antagonistic to modernity and suspicious of democracy.

\section{Sparking The Syrian Rebellion}

While the Syrian rebellion is thought of as part of the larger Arab Spring it is geography, including its human domain that is a significant dynamic igniting the fires of the Syrian civil war. A combination of drought and usually bad Syrian agricultural policies in the early 2000s created an environment ripe for rebellion. Following Bashar Assad's ascension to power in 2000 Damascus sought entrée into world agricultural 


\section{Journal of Terrorism Research}

markets but badly mismanaged water resources by encouraging the production of wheat and cotton, both water dependent cash crops, concurrent with the beginning of a severe drought.[3] In what may be one of the first politically significant impacts of global warming a decade of extreme and unrelenting drought encompassed the al-Jazira desert straddling Iraq and Syria along with the adjacent marginal steppe lands (Badia) in eastern Syria. Consequently the underground aquifers across the region were ultimately depleted by roughly $60 \%$ through the digging of illegal wells. [4] This unusually punishing drought also displaced nearly a million Syrian farmers and herdsmen who migrated to towns and cities in search of work forcing approximately two or three million out of a population of twenty four million thrust into extreme poverty. [5] The intensity of economic deprivation was heavily focused in the eastern Governorates of Deir ez-Zor, Hasakah, and Raqqa.[6] In the words of Kilcullen and Rosenblatt this displacement "Fueled by economic necessity and a persistent drought, these villagers created vast, insulated neighborhoods of urban poor." [7] The Assad government was not expecting this influx of displaced persons and had no security infrastructure in place to monitor the displaced population. Urban Syrian social structure at the time was defined by family groups and family branches (Bayt) while rural areas immediately prior to the rebellion could still best be described in terms of tribal hierarchies. [8] Geographically these shantytowns surrounding the cities and towns where Assad's Political Security infrastructure was less well developed later directly correlated with areas of Sunni militia strength. Examples of this include the Baba Amr area of Homs subsequently controlled by the Liwa al-Haqq battalions; the Ghouta and Harasta region of Damascus later dominated by the Liwa al-Islam militia now part of Jaysh al-Islam; and the eastern shantytowns of Aleppo currently controlled by an array of Sunni militias encompassing Asala wa al-Tanmiya, Jaysh al-Muhajirin al-Ansar (mostly made up of ethnic Chechens), Suqour al-Sham (by 2015 absorbed into Ahrar al-Sham) and now Islamic State militia fighters.[9] Those internally displaced rural peasants pouring into Syria's secondary towns and cities as well as the urban areas of Aleppo and Damascus changed the human geography of Syria and provided a ready source of unemployed and desperate young men who could ultimately be mobilized in rebellion.

The seminal event giving rise to what was initially seen as a democratic revolt is usually described as a series of increasingly violent demonstrations in Daraa south of Damascus in response to the torture of several teenagers who were accused of writing anti-Assad graffiti at the Daraa headquarters of Atef Najeeb's Political Security Branch. Daraa is a relatively underdeveloped and heavily Bedouin town situated on the Hawran plateau and those first demonstrations organized by the al-Zu'bi and al-Masalmeh clans were as much protests against the thuggish response to teenage graffiti as they were aspirations for political change. [10] The human terrain of Daraa was demarcated by a clan structure of unusual depth which could sustain a popular response against the thuggery of Assad's Political Police. Clans including the Abu Zeid, Zu'bi, Harris, Masalmas, Muqdad, Jawabra, and Mahamid had relationships extending across the southern border into Jordan and into the Jordanian town of al-Ramtha.[11] When the revolt began in earnest these clan connections stretching from the Nassib-Jaber crossing to the Arabian Gulf would ultimately provide important smuggling channels for money and arms trafficking sustaining the rebellion.[12] Over the course of the uprising the relationship between the Sunnis of Daraa and their Druze neighbors east of Daraa who were ostensibly neutral but somewhat supportive of Assad became increasingly strained.[13]

Although the Daraa incident is as reasonable a starting point as any other the significance is that unlike other revolutions in what is now referred to as the Arab Spring the Syrian demonstrations begin in a fairly small agricultural hub rather than the capital city. Part of the explanation here may be in the economic plight of these secondary cities as compared to central Damascus and Aleppo. James C. Davies concept of relative deprivation also called the "J-curve" theory of revolutions provides some understanding as to the timing 


\section{Journal of Terrorism Research}

as well as the geographic ignition points of Syria's rebellion.[14] Davies explained that economic progress followed by a sharp economic reversal can leave a population desperate for recovery and amenable to rebellion.

While Damascus and Aleppo were somewhat insulated from economic hardship because of their importance to the Assad regime the smaller agricultural cities bore the brunt of economic setbacks. Those farmers and herdsmen displaced by the severity of the drought and loss of their livelihoods and now in the shantytowns of Syria's secondary agricultural cities had known better times. The hopelessness of their economic circumstances still required what Martha Crenshaw referred to as an 'entrepreneur" to channel this hopelessness into open revolt.[15] In Daraa this role was played in part by Sunni Ulama as Ahmad al-Sayasne the Imam of the 'Umari Grand Mosque and the city's Mufti Rizq Aba Zayd joined the demonstrations.[16 ]

The outbreak of the Syrian Revolution thus has an identifiable geographic direction. The geography of the Syrian Revolution is initiated first in multiple secondary towns and cities and only thereafter moves into the shantytowns surrounding Damascus and Aleppo.[17] While Damascus and Aleppo had some demonstrations it would be a full year before these cities saw armed insurrection.[18] Shortly after the spark in Daraa for example the first "Day of Rage" demonstrations was in Hasakah in eastern Syria during early February of 2011 with its population swollen by despairing and impoverished farmers who had formerly produced nearly $50 \%$ of the countries wheat and cotton.[19] The Governorate of Deir ez-Zor so directly impacted by the drought along with its capital of Bu Kamal was "immediately and intensely mobilized" after Daraa with large and ongoing anti-Assad demonstrations.[20]

An ancillary political space affiliated with Syria's human geography permitted organizational activity later used to expedite rebellion was unintentionally created by Bashar Assad's wife Asma Assad. Asma Assad facilitated the creation of state sanctioned charities under the Union of Charitable Associations (itihat jamiat al-Kharia) that were allowed to network with minimal supervision by the security services. By April of 2011 local Coordinating Committees organizing demonstrations against Bashar Assad were exploiting these networks to mobilize the rebellion.[21] By the first week of May 2011 armed clashes were taking place in the Baba 'Amru neighborhood of Homs.[22]

As demonstrations spread to more cities and towns across Deir ez-Zor, Homs, Idlib and even Latakia Governorate the Assad regime's decision to crush rather than co-opt the demonstrations led to the Darwinian consequences where moderates were squeezed out and only the most radical anti-Assad actors survived. With moderates driven out, the popular counter narrative to Ba'athism was voiced through Salafi Jihadism at war with both modernity and, in Syria, at war with the House of Assad.[23] The uprising against Assad ultimately left the nominal government in Damascus spent with an unreliable Sunni dominated Syrian Arab Army (SAA), a wrecked national infrastructure, and major cities devastated by the Syrian fratricide. [24] The collapse of Assad's governing authority across Syria saw a rising era of militias establishing petty fiefdoms across Syria correlating with Syria's human geography. These militias acted as both proxies for external powers and as native participants in Syria's civil conflict.

The Syrian civil war is another arena for the larger contest in the region between Iran and Saudi Arabia who lead competing coalitions. The Iranian coalition on one side organizes both state and non-state actors to intervene in the Syrian civil war. Saudi Arabia confronts the Iranian coalition with a Saudi alliance of states, private donors from the Gulf and a secondary tier of Jordanian, Israeli, and Western participants of varying reliability.[25] Saudi Arabia and Iran who had supported their own favored proxies in Lebanon for decades now have expanded that conflict across Syria and ultimately into Iraq.[26] 


\section{Journal of Terrorism Research}

\section{Urban and Rural Militarization of the Rebellion}

Militia groups as they emerged across Syria during the middle of 2011 and 2012 followed a geographically discernable pattern generally correlated with the geographic patterns of the initial anti-Assad demonstrations. Militias tended to grow first in rural areas and secondarily in towns and cities. These militias initially aimed at merely protecting anti-Assad demonstrators and only later becoming dominated by Islamists bent on actually overthrowing the Assad government. Urban militias by contrast, first in Damascus and later in Aleppo, would evolve after the rural militias and following the disintegration of Assad's Syrian Arab Army in the middle to latter days of 2012.

The urban militias in their evolution were divisible into pro and antigovernment organizations. The rural militias developed first as spontaneous anti-government organizations only later were pro government rural militias conceived as part of Iran's strategy to save Syria. The pro government militias in the central cities began as reasonably spontaneous neighborhood self-defense organizations mobilized by fear of Sunni Jihadist and it was these militias that were later co-opted by the Assad government under the National Defense Forces (Quwat al-difa al-Watani) umbrellas. Particularly in Damascus and Aleppo the merchant class while socially conservative was also secular and disinclined to support Salafi Jihadism.[27] It was this generally Sunni merchant class that continued to support Assad if the alternative was a return to a romanticized vision of the 9th century. The anti-Assad militias made up of young men displaced by economic hardships would characterize organizations controlling the shantytowns surrounding these central city cores.

The rural divisions respecting support for the Assad government in Damascus were anchored in tribal division's resultant from decades of Ba'athist governing strategies. For example the Aneza tribal confederation in central Syria saw the Haddiyon tribe generally remain loyal to Assad, while the Turki, Fawa'ira, and Nu'im's mostly joined the revolution.[28] In some instances defections punctuated changing tribal alignments. The 2012 defection of the Syrian envoy to Iraq Nawaf al-Fares of the al-Jarrah clan for example helped to move the Egaidat tribal confederation into the anti-Assad column. The Hasanah, Bani Khaled and Aqaydat tribes all had had factions supporting both the regime and the opposition.[29] The Saudis whose Nejd tribes have historic linages with Syria's Anzea and Shammar tribal confederations have taken advantage of these tribal networks to provide material support to the anti-Assad rebellion.[30]

In Syria’s geographically eastern Governorates of Hasakah and Raqqa local tribal leaders in the rural steppe country (Rif Badia) were initially opposed to the rebellion in contrast to the towns of those Governorates. [31] The Assad dynasty (Hafez and Bashar) had used Syria's tribal confederations over the years to balance any appeal of the Muslim Brothers (Ikhwan) so some of these tribes such as the Tay, Fad'an and al-Jabbur felt beholden to the regime and have generally remained loyal to Assad. Others such as the Shammar confederation made up of the al-Khursah and al-Aslam tribes have supported the rebellion.[32]

\section{Al Qaeda and Sunni Extremism in Eastern Syria}

The Syrian civil war that shattered state institutions by 2013 also effectively highlighted overt sectarian geographies across the region.[33] The Sunni aligned communities that initially aspired to democracy and fought Assad in the north and south however were weakened by both internal divisions and Western dithering over arms. Several major Sunni formations coalesced and disintegrated until a reasonably coherent body began to fight the Assad regime under the moniker of the Islamic Front in November of 2013.[34] This front included Aleppo's Twaheed brigade under Adnan Bakkour and supported primarily by Qatar and the Jaysh al-Islam (Liwa al-Islam) in Damascus under Zahran Alloush and backed by Saudi Arabia. 


\section{Journal of Terrorism Research}

[35] Abu Issa's Suqour al-Sham originating in the Jabal al-Zaqiya of Idlib fought in both the Aleppo and Idlib Governorates although it was ultimately weakened by clashes with the Islamic State in Iraq and Syria (ISIS).[36] Some traditional Sunni Salafi organization's like Ahrar al-Sham (Harakat Ahrar al-Sham alIslamiyah, HASI or Islamic Movement of Free Men of the Levant) incorporated fighters that could align with traditional ideologies along the lines of the Ikhwan who would theoretically participate in elections but also included more militant Salafi Jihadists who did not believe in Western style democracy.[37] Harakat Ahrar al-Sham was one of the largest organizations under the Islamic Front whose resilience was demonstrated in the organizations recovery following the assassination of its entire first and second tier leadership by an Islamic State suicide bomber in September of 2014.[38] The Syrian Branch of the Ikhwan led in 2014 by the elderly and weak Mohammed Riad al-Shaqfa never successfully rebuilt the Brotherhood infrastructure eviscerated by Hafez al-Assad in 1982.[39] The Brothers have made some half-hearted attempts to engage the Revolution but do not have enough fighters or organization to be serious actors. Those organizations are now overshadowed by the black banners of al-Qaeda (Qa'idat al-Jihad) related Jihadis rising across Syria's east. [40] The rise of these Salafi Jihadist Organizations whose numbers are strengthened by foreign fighters changed the nature of the war as they displaced Assads' moderate opposition. The largest concentration of Salafi Jihadists in the world are now fighting from Syria to Iraq with tens of thousands of men under arms. [41] The regional and to a limited extent global impact of these Salafi Jihadist organizations and their fighters forged in the fires of the Syrian civil war will be felt for decades.

The creation of the Islamic State of Iraq and Syria (Dawlat al-Islamiyah fi Iraq wa'l-Sham, DAESH, or ISIS) under Abu Bakr al-Baghdadi (Abu Duaa) [42] in the spring of 2013 contesting the battlefronts of Syria incorporated a wide range of both indigenous and foreign Jihadists under the black banners of ISIS[43]. There are several instances of ISIS simply absorbing similar militant groups such as Jamaat Ansar alIslam.[44] These actors absorbed into ISIS range from Westernized 'war tourists' of Muslim extraction to thousands of Sunni prisoners freed from Syrian and Iraqi jails in ISIS raids. Many of these prisoners were genuine criminal sociopaths using the ISIS rubric to mask criminal enterprise leaving a heterogeneous range of Jihadi types fighting across the theater.[45] Additionally al-Baghdadi demonstrated some regional influence by requesting and receiving both trainers and fighters from the Pakistani Taliban (Movement of Pakistani Taliban, Tehrek-e Taliban Pakistan, or TTP). Taking an approach similar to the Islamic State (IS) the Pakistani Taliban facilitated a prison break in northwest Pakistan's Dera Ismail Khan Prison which freed several hundred Taliban prisoners who were then moved to Syria to fight with the IS. [46] The breadth of eastern and northern Syria by 2014 then became Salafi badlands where Sunni militias were directly impacted by Abu Bakr al-Baghdadi's Salafi ISIS fighters[47]

The geographic focal point of these Sunni badlands was the eastern Governorate of Hasakah in the epicenter of the Syrian drought. Hasakah links the corridor between ISIS controlled cities of Raqqa and Mosul as well as the Kurdish lands straddling Syria and Iraq. Hasakah city itself is divided between Assad regime National Defense Forces and Kurdish People's Protection Units (YPG) ruling competing districts of the city while surrounded across the rural spaces of the Governorate by ISIS and affiliate Salafi Jihadist fighters. [48] By the early summer of 2014 these Sunni badlands in Syria's east and the Sunni towns in western Iraq were subsumed under the Islamic State (IS) rubric as ISIS renamed itself following a series of victories across the Syrian and al-Jazira desert and into the central provinces of Iraq dramatically changing the nature of the war. [49] Operationally IS fighters did not try to overwhelm militarily the more populated cities and towns it conquered. Rather they would penetrate the security infrastructure from within exploiting local corruption to dominate local criminal enterprise.[50] IS thereby created revenue streams to the organization and used 


\section{Journal of Terrorism Research}

local criminal talent to identify politicians and security officials who could not be intimidated and assassinate them. [51] When IS did overtly overrun a given town or city there was less active resistance to the IS as local authorities by then were essentially collaborating with them.[52] The IS, even with several thousand men under arms, has relatively few heavy weapons and fights with fairly small formations and would have great difficulty overrunning any large town or city that was actively resisting. In the Sunni areas of Iraq the IS has been strengthened by making common cause with secular Ba'athists remnants of Saddam's army some of whom are calling themselves the Naqshbandi Army (Jaysh Rijal al-Tariq al-Naqshbandi or JRTN).[53] This marriage of convenience is playing a significant role sustaining the IS in Iraq's Sunni regions. The alliance is not a natural one however and it is a point of cleavage in the IS.[54]

The IS is manifesting some characteristics novel to the Syrian War and lacking in the first incarnation of AlQaeda in Iraq or the Islamic State in Iraq. The IS is now demonstrating some ability to govern. They chose Azhar al-Obeidi for example, a Ba'athist ex Iraqi army General who is a respectable figure and certainly no Sunni extremist as Governor of Mosul.[55] That ability to govern and hold territory is critically important if the effort to overthrow Assad is to ultimately be successful. Al-Baghdadi's command structure has now expanded and includes a three man military council now led by Omar al-Shishani and a set of twelve deputies and regional commanders including Ali al-Anbari responsible for Syrian territories under ISIS control. They apparently operate with some autonomy but coordinate through some shared networks. [56] It is in Raqqa however that IS governance is most well developed. According to the Institute for the Study of War the IS is dividing Raqqa's government into two categories; Administrative and Muslim Services and they are in fact running municipal government.[57] The IS also seems to be intentionally separating local police from religious police (al Hisba). The religious police look to have a mission of promoting virtue and preventing vice that at least takes inspiration from the Saudi religious police with a comparable mission. [58] While mocked in many quarters by Sunni religious authorities for its pretensions the Islamic State's declaration of a Caliphate under al-Baghdadi, now referring to himself as Caliph Ibrahim, may have an unappreciated inspirational value to potential Jihadis. Sayyed Qutb argued that Islam could not be fully practiced without a Caliphate and young Jihadis looking for a cause may be unpersuaded by the scholarly and jurisprudential shortcomings of a self-proclaimed Caliph. [59] The desire of young Jihadists to be part of something historic and bigger than themselves and the inspiration of a Caliphate to those young Jihadists should not be underestimated.

The Islamic State's Syrian branch was able to develop in part because the Assad regime focused its military efforts in western Syria on the relatively more moderate opponents of the regime. The Assad regime's master narrative argued for a choice between Assad or al-Qaeda affiliated Sunni extremists. [60] Trying to destroy the moderate opposition while more or less ignoring al-Nusra and the then ISIS furthered that narrative since the moderates were the real and immediate political threat to the Assad dictatorship. The inability of the moderates to organize themselves into a credible army and the failure of Western powers to provide genuine support for the moderates on the ground have probably doomed any prospects of regime change that is not antagonistic to Western interests. Now that the IS has emerged as a more credible entity both governing and holding territory is has come to the attention of outside powers including the United States which is making limited kinetic efforts to contain it.

The creation of the IS means that Sunni Salafi fighters from Iraq which heretofore had to move into Syria through formal border crossings in addition to the informal trade and smuggling routes can now move as if there were no border at all.[61] This was facilitated in part, by common tribal affinities as the Aneza, Shammar, Aqaydat and al-Jabbur tribal confederations span both sides of the former border between Syria 


\section{Journal of Terrorism Research}

and Iraq.[62] Iraq's Shi'a dominated nominal government allied with Assad, is now limited to the south of Iraq and unable to prevent Iraqi Sunnis from joining the fight in Syria.

In early 2014 the al-Qaeda core leadership in Pakistan speaking in the name of Ayman al-Zawahiri had attempted to renounce ISIS as an al-Qaeda affiliate knowing that ISIS and its precursor entity the Islamic State of Iraq (ISI), had a history of alienating local Sunni populations. This renunciation received less attention than it probably deserved in that there are not prior instances of al-Qaeda overtly renouncing initially affiliated organizations.[63] Salafi notables including Abu Muhammad al-Maqdisi and Abu Qatada al-Filistini both denounced the Caliphate of Abu Ibrahim and other al Qaeda affiliates have generally refused to enter into a bayat with the IS. [64] The rival Jabhat al-Nusra (the Victory Front sometimes called al-Qaeda in Bilad al-Sham) with more native Syrian fighters under Abu Muhammad al-Julani is al-Qaeda's preferred associate militia in Syria.[65] Al-Nusra was nominally populated by native Syrian Jihadis known locally as muhajereen yet they also contain some ethnic or nationally characterized formations. Libyan Jihadists for example, organized under Mahdi al-Harati's Military Umma Brigade and Sefian al-Kumi's Abu Salim Brigade have fought with Jabhat al-Nusra.s Ongoing friction between native Syrian Jihadists and foreign fighters within al-Nusra may become increasingly significant.

The emergence of the Caliph Ibrahim's Islamic State however may be an argument that the idea of alQaeda itself is outdated. Al-Qaeda was born as an administrative and logistical shell originally organized by Abdullah Azzam as a "Services Office" (Maktab al-Khidamat) to facilitate Jihadist resistance against the Soviet occupation of Afghanistan thirty years ago. It may be less a matter of al-Qaeda as an organization factionalizing but more the concept of an al-Qaeda that factionalized with multiple Salafi related Jihadi organizations claiming piety representing Companions of the Prophet while fighting one another.

The rebellion is still aimed at the Assad regime but much fighting occurs between the militia fiefdoms created by rebel formations as a result of intra Salafi disputes particularly in the northern tier northeast from Aleppo and along the Turkish border where the IS has tried to extend its influence.[67] The Border between southeastern Turkey and northeastern Syria is quite porous and has been one of the major regions for entry for foreign fighters moving into Syria. Geographically northeastern Syria is also the area where we are seeing the emergence of a viable Kurdish state. The Kurdish Peshmerga heretofore have been content to defend their town territories from the IS and use the opportunities presented by the Syrian war to build Kurdish national infrastructure. The predominately Sunni Kurds, although they have been betrayed repeatedly by Western powers over the last century, are playing a role quite similar to Jordan in their amenability to Western interests.[68] That role includes affiliating the Kurds with other 'at risk' local minorities. The Kurdish Peoples Protection Units (YPG) therefore historically facilitated alliances with local militias defending minority communities in northeastern Syria even before the civil war. The Kurds, for example, supported the creation of the Kings Peacock (Malik al-Tawus) militia in 2007 to protect the Yazidi community and in 2008 across the border in the Nineveh Governorate in Iraq Sabah Behnem working with the Kurdish Asayish developed a Qaraqosh Protection Committee to defend local Assyrians. [69] In the current rebellion the Kurds helped propagate the small Syriac Christian militia Sutoro founded in Qamishli during March 2013.[70] Kurdish actors then generally remain in their historically defined territories while assisting and / or affiliating with adjacent ethnic minority militias to secure their geographic space. Unlike the Salafi Jihadi Organizations the Kurds are better understood in terms of establishing national infrastructure than creating petty militia fiefdoms. 


\section{Journal of Terrorism Research}

The various formations within al-Nusra may become more enamored with the vision of the IS if the territories under Caliph Ibrahim's control continue to expand. In practice however an interlocking matrix of Salafi groups on the ground in Syria coalesce and disintegrate as local truces and alliances between Salafi are made and broken.[71] One of the characteristics of militia formations, both urban and rural across the Syrian space, is the creation and disintegration of truce arrangements between rival formations. Since all of the militias have intrinsic military weakness as compared to regular army formations the truce has become the vehicle to most effectively use the military capacity of a militia organization allowing them to focus their military efforts on targets left out of the truce arrangement.[72] It is also this process that is the basis for creating the transient militia fiefdoms.

\section{Southern Syria}

The war in southern Syria with its more compact geography is characterized by a different militia dynamic than other parts of the country. Geographically the wheat growing Hauran plateau and the three provinces of Deraa, Quarteira and the Druze province of Sweida define southern Syria.[73] The Amman - Damascus highway that transects the region was well known for smuggling before the Syrian civil war and served a similar function following the outbreak of the rebellion. In some areas near Daraa al-Julani's al-Nusra is established and other Salafis' are trying to become established although Islamic State fighters have so far been unsuccessful in creating a significant presence. There is considerably less Salafi influence in the Sweida region of the south where Syria's Druze live. The Druze Jaysh al-Muwahideen (Army of Monotheists) militia has been generally neutral in the conflict preferring to protect their own mountain communities rather than taking sides[74] The Druze share some analogs with the Kurds in that they are content to defend their own region although unlike the Kurds the Druze have no interest in creating a state. Israel, Jordan, the U.S. and Saudi Arabia also cooperate in this region to support rebel operations with semi-vetted pro-western militias such as the Liwa Yarmouk under the Zu'bi Bashar al-Zu'bi against Damascus and to move war material and fighters across the border.[75] Unfortunately the political theater of multiple re-organizations of Sunni fighters from the more democratically oriented Free Syrian Army (FSA) to the Syrian Revolutionary Front in futile efforts to exclude al-Qaeda related Salafi extremists have proven fruitless in a war where the Salafi Jihadists are the most effective combatants. [76] Nonetheless Assad's Syrian Arab Army formations out of Nawa sporadic attempts to hold the motorway running between Damascus and Sunni controlled Daraa have been less than successful.[77] The SAA struggles to do anything beyond trying to secure portions of the highway for the Assad regime having lost the balance of the adjacent territory to the Druze or to Sunni rebels.[78]

\section{Shi'a Militias and their Affiliates in Western Syria}

As the Syrian civil war has now evolved into a generalized Sunni revolt the shape of todays' conflict against the House of Assad is affected by the decision of Damascus to ally itself with Iran a generation ago. The ostensively secular but now shattered Syrian Bäathist regime originally made common cause with Iran in the 1980s and in the years after the death of Hafez al-Assad in 2000 Syria effectively became an Iranian dependency.[79]

While Khomeini's concept of Velayat-e Faqih governance is challenged domestically by Iran's own struggle with economic and social modernity the Syrian civil war, which is now engulfing Iraq, directly confronts Iran's Supreme leader Khamenei with a looming catastrophe.[80] Tehran is facing in Syria something close 


\section{Journal of Terrorism Research}

to an existential threat to its vital national interests. The rivers of Sunni blood flowing from Assad's efforts to crush the rebellion means any successor Sunni government in Syria must be hostile to Tehran. A hostile Sunni government in Damascus along with a fractured Iraq endangers the totality of Iran's Resistance Axis (Jabhat al-Muqawama) from the Levant to the Persian Gulf. "Saving Syria" then has become second only to the acquisition of nuclear weapons in Tehran's hierarchy of needs lest Iran lose the regional influence it has gained since the 1979 Revolution.[81] Tehran's ability to "Save" Syria however is complicated by the complex intra-Iranian political matrix of relationships between clerics, the bonyad (controlling various economic assets), the Revolutionary Guard (Pasdaran or IRGC) and other Iranian security organs that compete for influence in an ever changing constellation of conflicting interactions. The politically contradictory aspects of this system are illustrated by Iran's incongruous relationship with al-Qaeda. Tehran simultaneously hosts numerous al-Qaeda facilitators who have used safe haven in Iran to move al-Qaeda money and fighters across Pakistan[82] while at the same time Tehran's Revolutionary Guard battles al-Qaeda linked fighters in both Syria and Iraq.[83]

The collapse of the Assad government has effectively left a Russian supported and Iranian dependent Alawite ruled canton originating in Latakia, abutting Lebanon and running south to Damascus.[84] Bashar al-Assad while feigning a role as President is in fact merely leading the largest militia in Syria and is little more than the local face of a larger Iranian occupation. The collapse of Assad ruled territories in Syria's east has enhanced the already existing concentration of internally displaced minorities including most Alawite, Christians, and some clans of neutralist Druze into areas of western Syria controlled by the Assad government.[85]

The resources needed by Tehran to save its Syrian dependency increased exponentially after 2011 as it became clear that Damascus could not contain the rebellion. Therefore what was initially Iranian intelligence and law enforcement assistance rendered through Syria's General Intelligence Department (GID) quickly developed into a military campaign directly managed by Iran's Revolutionary Guard.[86] This campaign relied on the targeted use of both expeditionary Quds personnel along with the limited deployment of IRGC Ground Forces experienced in internal Iranian security operations. [87 The question then becomes how long an Iranian government significantly weakened by Western economic sanctions can afford to support this Syrian adventure before the flames of rebellion begin to smolder in Tehran.

Following the initial effort Iran's Revolutionary Guard changed tactics and attempted to fortify the Assad regime by organizing an array of praetorian auxiliaries built on a coalition of Shia affiliated militias.[88] Geographically these militias are intended to protect Syria's western urban centers and the internal lines communication that connect them. These Shia formations were organized by Iran's Revolutionary Guard and Lebanon's Hezbollah and incorporated the existing Alawite Jaysh al-Sha'bi (Quwat al-Difa'a al-Watani) built by local Alawite Popular Committees during 2012 in urban core of Damascus. [89] While initially fairly unstructured the ongoing development of Jaysh al-Sha'bi was funded by Tehran as Pasdaran Quds seized on this opportunity to establish control over these local urban militias and use them as proxy forces supporting the Assad regime.[90] Called the National Defense Forces by the Assad regime the Jaysh alSha'bi worked with a variety of other lesser known pro-regime militias. The Ba'ath Battalions for example appear to have originated in Aleppo under the auspices of a local Ba'ath party leader Hilal.[91] Like the Jaysh al-Sha'bi it is lightly armed and looks to merely relieve the army by manning checkpoints and the like. The Ba'ath Battalions militia idea has expanded now to several thousand fighters although good portions of those fighters are serving in the less dangerous coastal regions around Latakia and Tartus[92] Some Baath 


\section{Journal of Terrorism Research}

Battalions have been directly involved in fighting in Aleppo and elements seem to be now emerging in the Alawite neighborhoods of Damascus also hosting Jaysh al-Sha'bi militia groups.[93]

Urban organizations like the Ba'ath Battalions are distinct from Jaysh al-Sha'bi in that they are less affiliated with the IRGC and articulate at least the pretentions of Bashar Assad's ideologically secular Ba'ath Party.[94] In 2014 the popular narrative defines this conflict as Shi'a affiliated pro-government militias versus Salafi Sunni anti-government militias but there remain a few ostensively secular formations on both sides such as the aforementioned pro Assad Ba'ath Battalions and the secular Iraqi Sunni Jaysh Rijal al-Tariq alNaqshbandi (JRTN) fighters allegedly aligned with the Islamic State.

Hezbollah is of course the most important of the Shi'a militias attempting to "Save Syria" for Tehran as well as itself.[95] Hezbollah is organized and operates differently than the Iraqi Shi'a militias fighting on behalf of Tehran in Syria. In southern Damascus for example a number of Iraqi Shi'a militias and Hezbollah fighters occupy the ground around the Sayyidah Zaynab and Sayyidah Ruqqaya Shrine complexes in Damascus, Bab Saghir Cemetery (also called the Sayyida Sukayna or Small Gate Shrine), and the Damascus Umayyad Mosque. These positions simultaneously hold territory in the capital while protecting the regimes air bridge to Iran via the Damascus airport.[96] One of the largest mixed Shi'a formations fighting in south Damascus is the Abu Fadl al-Abbas Brigade using a common moniker to aggregate several distinct Shi'a militias with roughly 10,000 fighters from Lebanon, Syria, and Iraq.[97] This Sayyidah Zaynab region facilitates local support for both Hezbollah and Iraqi Shi'a militias as it is also the region of Damascus settled by Shi'a refugees from earlier wars in Iraq so may constitute an identifiable Shi'a militia fiefdom as the war drags on.[98]

The Lebanese Hezbollah deployment aimed at saving Hezbollah as well as saving Syria is focused in the spaces abutting eastern and northern Lebanon in Syria.[99] The Hezbollah militia fighters are definable as a hybrid between special operations type groups and neo-guerrilla groups configured in a way approaching conventional military formations and meant to buttress the Syrian army on the ground.[100] In this sense Hezbollah is functioning as neither an urban nor a rural militia but something more akin to a small but more traditional military formation acting under Iranian command. Hezbollah's geographic deployment in Syria's western spaces supports a range of configurations. In and near Lebanon proper Hezbollah deploys in defined operational units. In the Qalamoun region it operates in tandem with the Syrian Arab Army while in other areas Hezbollah cells are embedded with Iraqi Shi'a militia formations. Hezbollah's initial deployments focused on efforts to secure Hezbollah's own historic arms supply route through Zebdani on the western side of Damascus which had been under effective rebel control for some time.[101] In western Syria when significant elements of the Syrian army are arrayed for particularly important battles Hezbollah appears to form what have been called "corseting" forces on the Syrian army flanks to strengthen the mediocre ability of the Syrian army to take and hold ground.[102] A Syrian army that is wanting in its ability to take territory is likewise middling in administering the territory it occupies. In the case of Qusayr for example the Syrian army's political unreliability means it is Hezbollah and not the Syrian army is really administering a militia fiefdom in the town.[103] Administration of Qusayr was important to Hezbollah because families from one of the organizations founding Hammadi clans lived there but it is also geographically important to the Assad regime as it links Damascus with the Orontes river valley through the Qalamoun Mountains into the coastal Alawite regions.[104] Although Hezbollah in theory controls Qusayr and, along with the Syrian army, the Qalamoun in fact there are still some thousands of rebel Sunni fighters operating in small bands harassing both Hezbollah and the SAA across that region.[105] 


\section{Journal of Terrorism Research}

Hezbollah's intervention in Syria in 2012 at the behest of Iran and to protect its own interests in Lebanon fundamentally altered the character of that organization.[106] Politically Hezbollah's resistance narrative is no longer tenable since Hezbollah is now party to a major war outside Lebanon in which Israel is not even an overt participant. Militarily Hezbollah is engaged in extensive counterinsurgency operations in a neighboring country defending an Alawite dictatorship against a popular uprising by a majority Sunni population.[107] The course of the Syrian civil war has also seen an historic expansion in the size of the organization as veteran fighters become casualties and less seasoned fighters replace them.

Iran's Revolutionary Guard while genuinely allied with Hezbollah are by contrast utilizing Iraqi Shi'a militias differently in their efforts to save Syria. Whereas Hezbollah has a hierarchy almost comporting with that of a conventional army operating under Iranian command the Iraqi Shi'a militias are much less coherently organized.[108] The Iraqi Shi'a militias also lack the experience and training of the original Hezbollah cadre who cut their teeth against the Israeli Defense Forces (IDF) in south Lebanon. Many in the Iraqi Shia militias fighting in Syria have minimal training and their only advantage over Assad's Syrian Arab Army is that the Iraqi Shi'a are politically reliable unlike Assad's supposed army.[109] They often fight under the name of the Abu Fadl al-Abbas Brigade as an umbrella organization for Iraqi Shi'a militias in Damascus.[110] Cadre from these Iraqi Shia militias were initially organized under the Iranian Special Groups fighting Americans in Iraq before the U.S. withdrawal in 2011.[111] They were first deployed across Syria in 2012 at Iran's directive but are now stretched as the Salafi Islamic State has split Iraq in half. This has relieved some of the pressure on Sunni Salafi Jihadists fighting in western Syria as some Iraqi Shi'a fighters return to Iraq to fight the Islamic State. Having said that Iraq's Iranian controlled Asa'ib al-Haq organization under Qais al-Khazali[112 ]and Abu Mahdi al-Muhandis's Kata’ib Hezbollah (Jaysh al-Mukhtar) still send fighters to Syria.[113] Kata'ib Hezbollah founded by Watheq al-Battat and deploying fighters in both Iraq and Syria is relatively more significant organizationally in part because al-Muhandis has an especially close relationship with Pasdaran Quds chief General Suleimani.[114] Asa'ib al-Haq (League of the Righteous) was founded about 2005 but has a growing expeditionary footprint in Syria.[115] Pasdaran Quds has deployed these Iraqi Shi'a militias fighting in Syria primarily to Damascus and Aleppo as these cities are most important to the outcome of the war. The Haidar al-Karar Brigade, for example, is deployed in west Aleppo with about 800 fighters under the leadership of the military chief of Asa'ib al-Haq Akram Abbas al-Kabi.[116] Asa'ib al-Haq has sent the greatest number of Iraqi Shi'a fighters to Syria[117] although Kata'ib Hezbollah has sent about 1500 fighters in three Brigades to Syria al-Hamd, Hassan Mujtaba, and Ammar Ibn Yassar.[118] Iran's objective is to use these Shi'a militias to push the Sunni fighters out of Damascus and Aleppo relegating the rebels to the eastern wastelands of Syria.

\section{Lebanon's Discontents}

Lebanon has historically been integral to Syria and so is inevitably engaged in the struggle for Syria. The petty fiefdoms being established by contending militias in Syria are beginning now to be reflected in Lebanon. While not entirely merging with the Syrian conflict the Syrian war is now directly impacting Lebanon with nearly a million Syrian refugees in the country and Sunni Salafi Jihadists initiating operations against Hezbollah in Lebanese territory.[119] This influx of Syrian Sunni refugees is demographically making Lebanon more Sunni and less Shi'a. The Bekka Sunni town of Arsal for example, now swollen from 40,000 to nearly 100,000 people has become one nexus for the spillover. The Sunni inhabitants provide significant logistical support for the anti-Assad rebels opposite Arsal and Tfeil in the Qalamoun region of Syria despite 


\section{Journal of Terrorism Research}

the efforts of the Lebanese Army and Hezbollah to prevent it.[120] There a potential for a Salafi salient to develop anchored in Arsal and creeping south on the western side of the Bekka.

Although there is not a significant militant Sunni tradition in Lebanon that is now changing as some segments of Lebanon's Sunni community become radicalized and Sunni Syrian refugees in Lebanon remain actors in the Syrian civil war. That radicalization is most pronounced in the rural areas of Lebanon particularly the northern Bekka although it is happening to a lesser degree in urban settings as well.[121]

In the fall of 2013 for example, ISIS car bombs struck Hezbollah facilities in Haret Hreik in south Beirut while the Salafi Abdullah Azzam Brigades directly attacked the Iranian embassy in the Beirut's Jnah area.[122] The northern Lebanese city of Tripoli, always divided from the time of Lebanon's civil war, is now witnessing an emergent kinetic struggle between various Salafist supporters of the Syrian rebels in the Bab al-Tabbaneh quarter and their Alawite neighbors abutting Jabal Mohsen.[123] The Lebanese Army deployed in Tripoli during April of 2014 as part of a security plan but the Lebanese army is itself now coming under fire. Likewise Sidon in Lebanon's south now sees regular fighting between Sunni Salafists and Hezbollah supporters. [124] The real danger from Hezbollah's point of view would be Salafi Jihadists from the Ain al-Hilwah refugee camp near Sidon developing modalities for Salafi Jihadi safe passage through the Iqlim alKharroub where there is significant Sunni population and then move north through the Sunni villages on the western side of the Bekka up toward Arsal.[125] The danger for Lebanon is this could create a band of Sunni zones from Arsal in the north, down the western side of the Bekka then cutting further west to Sidon on the coast. This would essentially split Lebanon in half with a zone of potential refuge for Sunni Salafi Jihadists.

The modus vivendi between the Lebanese Army and Hezbollah following the 1989 Ta'if accords had been predicated on the army limiting its activities to maintaining security over the various Palestinian camps in Lebanon. Those Palestinian Camps were inadvertently destabilized by Bashar Assad himself when he placed Syrian Jihadist fighters returning from operations in American occupied Iraq in the Lebanese Palestinian Camps to prevent them from threatening his government.[126] In 2005 Syria had been forced to withdraw its occupation army from Lebanon and placing these returning Jihadist fighters in Lebanese Palestinian Camps seemed like a way for Bashar Assad to maintain influence in Lebanon. However Fatah al-Islam (in Nahr al-Bared Camp) and Usbat al-Ansar (in Ain al-Hilwah Camp) became the nucleus of a Salafi Jihadi network now facilitating operations in Syria against Assad and creating space in Lebanon for Sunni Salafi Jihadists to grow.[127] Consequently the Ta'if understanding is now secondary as the Lebanese Army attempts to suppress Sunni militants in Tripoli and Sidon while avoiding involvement in the larger Syrian conflict. Nonetheless the Lebanese Army's $2^{\text {nd }}$ and $6^{\text {th }}$ mechanized infantry brigades and $1^{\text {st }}$ and $2^{\text {nd }}$ border regiments deployed in northeastern Lebanon are slowly becoming belligerents supporting Hezbollah and the Assad government against the Sunni rebellion[128]

\section{Conclusions}

When Syrians first rose up in search of democratic reforms as the Arab Spring moved across the Levant the country was not a failed state. Bashar al-Assad's thuggish attempt to bludgeon into silence the moderate Syrian cry for freedom did however succeed in destroying the Bathist state his father built. The ethnic and religious geographies that characterized twentieth century Lebanon's civil war had their analogs in Syria but the Syrian experience is not merely reflective of Lebanon. Historically Lebanon has been the economic driver of commerce in Syria and western Syria will remain dependent on Lebanon for economic viability whatever the ultimate permutations of Syria's civil war.[129] Syrian ethnic and religious geographies were animated 


\section{Journal of Terrorism Research}

by a Salafi Jihadism at war with modernity and the determination of imperial Iran to hold the gains of its twentieth century revolution.

Syria's democratic revolutionaries themselves fell victim to men more ruthless in political ambition. The disciples of Syrian democracy saw their revolution hijacked by Salafi Islamists seeking not only the destruction of the Ba'athist state but the restoration of a version of Islam allegedly followed by the Companions of the Prophet. The battle in Syria grew into one between Salafi Jihadism and Iran's local procurator in Damascus Bashar al-Assad. The Western powers stepped back and contented themselves with allowing sufficient support to reach the Salfists and the smattering of democratic fighters to bleed Tehran and its allies on the battlefield but not aid sufficient to defeat Assad and allow the Salafists to come to power.

It is now possible to articulate some observations about the qualitative pattern of militia development and accretion of militia dominated petty fiefdoms across the geography of Syria. In the timeframe since the outbreak of the rebellion in 2011 we have seen an emergence of increasingly complex relationships between anti-Assad militias. The raw number of militias fighting the Assad regime increased dramatically in 2012 along with a slower increase in their military capacity and growth of spaces dominated by militia fiefdoms that continued into 2013 and 2014. A shifting constellation of alliances and truces particularly between various Salafi militias and the geographic areas they controlled characterized inter militia relations. The cumulative breakdown in Assad's governing authority across the country provided less governed spaces conducive to both militia growth and the petty fiefdoms. The involvement of external powers also followed this general trend with greater and greater involvement from 2012 forward.

While there are literally hundreds of militias across the Syrian battle space coalescing and disintegrating as truces and alliances change all the militias are not equally relevant. Major Casey Mills of the U.S. Army created an approach for assessing terrorist threats relevant to understanding Syrian militias with focus on scale, scope, and salience. Mills argues that scale defines the size and capabilities of the organization, scope looks at the ability or desire of the entity to extend its area of operations and salience examines the importance and resonance of the groups' message and objectives.[130]

The anti-Assad militias with their focus in rural spaces appear to be coalescing into three general groupings. The first grouping consists of the so-called moderate militias whose fiefdoms exist in pockets of north central Syria and in the south adjacent to Jordan. These militias have been marginalized with much of their leadership outside the country and compromised to Western powers not much interested in a military victory over Assad. These militias are small and are intentionally limited in their capabilities as their Western sponsors are not seeking an outright military victory over Assad. The ability of these groups to expand their area of operations is limited secondary to the minimal support delivered from those sponsors. Their salience is problematic because their lack of military capacity makes them irrelevant. The second major grouping is defined through the Islamic Front coalition now defined primarily by Ahrar al-Sham and affiliated factions ruling multiple petty fiefdoms immediately adjacent to the Syrian rump state from Latakia south along with Jabhat al-Nusra abutting Lebanon and terminating in Damascus. These militias are Salafi Jihadist in orientation but sympathetic to the ideology of Hasan al-Banna's Muslim Brotherhood in terms of their willingness to engage non-Islamic elements to reach an ultimate goal of Islamic governance.[131] While these groups generally have no frank affiliation with the Ikhwan they do adopt Hasan al-Banna's thought as distinct from Sayyed Qutb's Leninist Vanguard Party approach in compromising with the modern world on the way to Ummah.[132] These militias are large and reasonably capable. They are sympathetic and / or affiliated with al-Qaeda but it is somewhat unclear whether they have any intentionality to expand operations outside 


\section{Journal of Terrorism Research}

Syria. They are more salient now than they were two years ago because the Salafi Jihadists have proven most relevant and most effective on the battlefield. The third grouping consists of Islamic State affiliated Jihadists whose fiefdoms govern in the eastern Syrian space while competing with Islamic Front formations in some northern regions. These Islamic State affiliated Jihadists incorporate transnational Jihad into their ideological worldview and for them the Syrian war is merely part of a larger struggle. Islamic State and affiliated Jihadi militias are large and reasonably capable although they rely on battlefield recovery for most of their arms and ammunition but have created their own revenue streams. They do, and in fact are, expanding operations outside Syria. The expansion is principally in Iraq with some efforts aimed now at Jordan. The message of a restored Caliphate clearly resonates with many impressionable Jihadist sympathizers outside Syria. It is the second and third groupings in Ahrar al-Sham, Jabhat al-Nusra and the Islamic State that have attracted the greatest numbers of foreign fighters.[133]

An era of militia dominated petty fiefdoms covered with an Islamist veneer then is likely to emerge across the whole of the former Syrian state with the political orientation of the various self-proclaimed Islamist Emirs dependent on the major sources of their political and material support as well as the audience to whom they are speaking in a given moment.[134]

In the western Syrian rump state defined by the Tartus Latakia Damascus axis these militia fiefdoms will likely be characterized by territories ruled through Shi'a affiliated militias of different configurations united principally by faux allegiance to Iran's Revolutionary Guard through the figure head of Bashar al-Assad. Here Assad is essentially another militia chief, albeit the largest one, beholden to a foreign patron. The threat in western Syria succinctly defined by Aaron Lund is the gradual disintegration of Iran's ability to exercise much authority through Assad.[135] Lund foresees the gradual unraveling of central authority even on the pro-regime side as the concurrent rise of local rulers operating with independent resources in ostensive regime controlled areas furthering a likelihood of militia dominated fiefdoms in western Syria. In the eastern expanses of Syria militia fiefdoms with a Salafi face will be more pronounced and adhere to disparate ideological currents flowing from Caliph Ibrahim's Islamic State and united in their rejection of modernity. The trend over time mirroring Lebanon's experience will be towards consolidation and a re-emergence of a Syrian state but an era of militia fiefdoms will likely precede it.

\section{About the author}

Carl Wege is a tenured Professor of Political Science at the College of Coastal Georiga. He has written a variety of articles on Hezbollah, Iran, and Syria. His biography is available on Linked-In.

\section{Notes}

[1]The general description of Bathism is an authoritarian ideology originated by Michel Aflaq and Salah albin al-Bitar deriving from fascist political ideologies in Europe. Ba'athists ostensively sought a "renaissance" of Arab culture and a single state under what Lenin would call a vanguard party. Sunni militants often refer to Alawites as "Nusairis" after the Alawite founder Abu Shuaib Muhammed Ibn Nusair an-Numairi (d. 868). The French renamed the Nusairis as Alawites during the Mandate period to emphasize their connsection to Ali and the larger Muslim community in an attempt to enhance political stability. Syrian Alawites divide into roughly four tribal groupings: the Haddadun, Khayyatun, Kalbiyyah, and Matawirah, with the Assads from 


\section{Journal of Terrorism Research}

the Numilatiyya clan of the Matawirahs. See Mahmude A. Faksh, “The Alawi Community of Syria: A New Dominant Political Force," Middle Eastern Studies 20, no. 2 (April 1984): 133-135.

[2] Ignacio Alvarez-Ossorio and Ignacio Gutierrez de Teran "The Syrian Ruling Elite and the failure of the repressive trend" in Political Regimes in the Arab World: Society and the Exercise of Power. Ferran Izquierdo Brichs ed. (Routledge, 2012), p. 189. Also included are the al-Hassan, Najib, Hamsho, and Hambouba, clans. See Bassam Haddad “The Syrian Regime’s Business Backbone” Jadaliyya 22 March 2012.

[3] "Drought helped cause Syria's war. Will climate change bring more like it?" Washington Post 10 September 2013.

[4] "Drought called a factor in Syria’s Uprising," Voice of America, August 20, 2013.

[5] Ibid.

[6] "Rural Poverty in Syria," Rural Poverty Portal http://www.ruralpovertyportal.org/country/home/tags/syria Accessed 20 May 2014.

[7] Kilcullen, David and Nate Rosenblatt, “The Rise of Syria's Urban Poor: Why the War for Syria's Future Will Be Fought Over the Country's New Urban Villages," PRISM Syria Supplemental Center for Complex Operations Volume 4, (2014), 33.

[8] "Urban and Rural Geography in Syria" Geographic Services Inc., 2011, www.geographic-services/net/ index.php/download file/view/112/210 Accessed 1 May 2015.

[9] Jaysh al-Muhajirin al Ansar (Army of Immigrants and Supporters) though Chechen has been publically supported by Saudi scholar-jurist Abdullah Muhammad al-Muhaysini. "Al Qaeda-linked Saudi cleric in Syria praises fighters from Islamic Caucus Emirate," Long War Journal, March 2, 2014. JMA originally affiliated with al-Nusra but later became part of the Islamic State. In addition to Chechans there are a significant number of Muslims from Western countries.

[10] Haian Dukham “Tribes and Tribalism in the Syrian Uprising” Syria Studies Journal (Volume 6 Number 2), pg. 8

[11]Nicholas A. Heras “A profile of Syria's Strategic Dar'a Province” CTC Sentinel Combating Terrorism Center 30 June 2014.

[12] Reinoud Leenders “Social Movement Theory And The Popular Uprising In Syria," Arab Studies Quarterly Volume 35, number 3, 278.

[13] The Druze generally maintain what can be described as an "active neutrality" theoretically acquiescing to the national authorities who theoretically exercise dominion over their territories while actually concerned primarily with the integrity of their own communities.

[14] James C. Davies, “Toward a Theory of Revolution,” American Sociological Review, 1962, 27(1): 5-19.

[15] Martha Crenshaw, “An Organizational Approach To The Analysis Of Political Terrorism," Orbis 29 (Fall 1985): 465-489.

[16] Thomas Pierret, Religion and State in Syria: The Sunni Ulama from Coup to Revolution, Cambridge, New York, Melbourne, Madrid, Cape Town, Singapore, Sao Paulo, Delhi, Mexico City: Oxford University Press, 2013, 216. 


\section{Journal of Terrorism Research}

[17] Aymenn Jawad Al-Tamimi and Oskar Svadkovsky, "Demography Is Destiny in Syria," The American Spectator February 6, 2012. The first protest in Damascus was also in February 2011 near the Souk alHamidiyah in the central city.

[18]Pierret, Religion and State in Syria: The Sunni Ulama from Coup to Revolution, 217.

[19] Carole A. O’Learly and Nicholas Heras, "Syrian Tribal Networks and their Implications for the Syrian Uprising," Terrorism Monitor, Volume X, Issue 11, 1 June, 2012. "Earth Is parched Where Syrian Farms Thrived" New York Times October 13, 2010.

[20] Concomitant with the aforementioned is a correlation, if not a causal relationship, between most of the Governorates that were the first to rebel and pre-revolutionary crime rates. The Governorates first involved in the rebellion Daraa, Idlib, Homs and Deir ez-Zor excepting Homs but in particular Daraa had the highest criminal conviction rates in Syria. See Reinoud Leenders and Steven Heydemann "Popular Mobilization in Syria: Opportunity and Threat, and the Social Networks of the Early Risers," Mediterranean Politics, Volume 17 (2), 149 and 151.

[21 Emile Hokayem, Syria's Uprising and the Fracturing of the Levant (Adelphi Books 2013), 69. Pro]testers also used smuggled cell phones and internet chat rooms to organize demonstrations in the name of Local Coordinating Committees about this time. See Fred H. Lawson, Global Security Watch: Syria, Santa Barbara California, Denver Colorado, and Oxford England: Praeger Press, 2013, 83.

[22] Lawson, Global Security Watch Syria, 84.

[23] Syrian Ba'athism is as outdated as Marxism in the Near East as the most powerful dynamics sweeping the region are now ethnic and Islamist. Democracy, Socialism, and Ba'athism have just failed politically and economically in most of the region. Democracy promotes social insurgency in the face of dictatorship but has not really survived as an end in itself. Democracy combined with Western style nationalism has functioned only in Israel where it is joined with ethnicity and, to a lesser extent, in Turkey. Egypt's experiment with socialism died forty years ago with Nasser and is a model for no one. Ideological Baathism with its Westernizing and material affectations have been obliterated in Iraq, failed in Syria, and exists only in the political margins of Lebanon and Jordan.

[24] Even setting aside the sectarian make-up of the Syrian Arab Army it was still ill-equipped to suppress a massive popular revolt. The Syrian Army consisted primarily of heavy divisions intended to fight Israel in a conventional war and was neither trained nor prepared to fight a widespread counterinsurgency campaign within Syria proper. The formations of the SAA that remained most loyal to Assad were the 4th Armored Division nominally commanded by General Mohamed Ali Durgham but de facto commanded by Assad's brother Maher al-Assad and the Republican Guard Division under Geneeral Shoaeb Suleiman headquartered at mount Qasioun west of Damascus. Now Syria's national infrastructure has been reduced to ruin the only thriving economic activity seems to be the local production of the illegal amphetamine called captagon.

[25] Charles Lister and William McCants “The Syrian Civil War: Political And Military State Of Play” War On The Rocks 14 February 2014. http://warontherocks.com/2014/02/the-syrian-civil-war-political-andmilitary-state-of-play/ Accessed 12 May 2015.

[26] The Saudi Intelligence Service (al-Mukkabarat al-A'amah or GIP) is the Government of Saudi Arabia lead organization in this effort. See also "Lebanon Caught in Middle of Iranian-Saudi 'Cold War"' Al Monitor 22 August 2013. 


\section{Journal of Terrorism Research}

[27] “Tentative Jihad: Syria’s Fundamentalist Opposition” International Crisis Group, Middle East Report Number 131, October 2012, 7.

[28] Haian Dukham "Tribes and Tribalism in the Syrian Uprising" Syria Studies Journal (Volume 6 Number 2), 15 .

[29] Dulhan, “Tribes and Tribalism in the Syrian Uprising," Syria Studies, 15. Syrian tribes are organized as national or transnational tribal confederations called Qabila and individual tribes called Ashira. The Ashira are divided into clans called fukhud, linages called Khums, and extended families called al-Bayt or aa'ila. See Nicholas A. Heras and Carole A. O’Leary, “The Tribal Factor in Syria's Rebellion: A Survey of Armed Tribal Groups in Syria," Terrorism Monitor, Jamestown Foundation volume 11, Issue 13, June 27, 2013.

[30] Dulhan, “Tribes and Tribalism in the Syrian Uprising," Syria Studies, 17.

[31] Syrian tribes divide into clans (asha'ir) and lineages (afkhed).

[32] Dulhan, “Tribes and Tribalism in the Syrian Uprising," Syria Studies, 15.

[33]Blowback from the Syrian war is also undermining Lebanon's fragile peace with the Oxford Research Group estimating that country to have absorbed nearly one million Syrian refugees.

[34] In 2014 the Islamic Front seemed to disintegrate although Ahrar al-Sham continued to use the moniker. The largest organizations in the Islamic Front included Ahrar al-Sham, the Twaheed Brigade, and Jaysh alIslam. See Aaron Lund "Islamist Mergers in Syria: Ahrar al-Sham Swallows Suqour al-Sham” Syria In Crisis Carnegie Endowment for International Peace 23 March 2015

[35] Lisa Lundquist "Analysis: Formation of Islamic Front in Syria benefits jihadists groups" Long War Journal 23 November 2013.

[36] Suqour al-Sham was effectively aborbed by Ahrar al-Sham in early 2015. See Aaron Lund "Islamist Mergers in Syria: Ahrar al-Sham Swallows Suqour al-Sham" Syria In Crisis Carnegie Endowment for International Peace 23 March 2015.

[37] Abu Khalid al Suri (Mohamed Bahaiah) was an al-Qaeda member who led Ahrar al-Sham until his death near Aleppo in early 2014 attack. Khalid did know Abu Mus'ab al-Suri thought to have been rendered from Diego Garcia back to Bashar Assad some years ago. Abu Mus'ab was an intellectual driver of the Islamist movement having penned several seminal treatises on resistance. See "Al Qaeda's chief representative in Syria killed in suicide," Long War Journal February 23, 2014. Ahrar al-Sham received significant financial support from Qatar which facilitated weapons purchases in Libya for the group and from Kuwait.

[38] Thomas Joscelyn "Head of Islamic Front, other senior leaders killed in explosion" Long War Journal 9 Septermber 2014.

[39] Raphael Lefevre "New Leaders for the Syrian Muslim Brotherhood" Carnegie Middle East Center 11 December 2014. Recently there have been efforts to re-establish Ikhwan as significant actors in Syria but those efforts are having only a marginal impact.

[40] Pro-Western groups including Bashar al-Zoubi's Liwa al-Yarmouk in Derra and Jamal Maarouf's Shuhada Souria in Idlib simply do not command enough fighters to be relevant any more. The recently created Saudi and Qatari funded Islamic Front incorporating Jaysh al-Islam which operates primarily in Damascus, Ahrar al-Sham one of the more directly Salafist factions with a history of cooperating with alQaeda, Suqour al-Sham active primarily in the Idlib region and Liwa al-Tawhid fighting in Aleppo allegedly exclude the overtly al-Qaeda affiliated Jabhat al-Nusra and initially declared al-Qaeda oriented Islamic State 


\section{Journal of Terrorism Research}

in Iraq and Syria but that is unlikely to prove any more successful than previous efforts to segregate Salafi Jihadists from al-Qaeda factions.

[41] The increasingly sectarian nature of the war has led to "dueling fatwa's" issued by prominent scholarjurists. Shaykh Yusuf al-Qaradawi based in Qatar issued a fatwa in the spring of 2013 supporting a Sunni Jihad against the Assad government. Grand Mufti Abdul-Aziz ibn Abdullah Al ash-Sheikh of Saudi Arabia supported al-Qaradawi. Ayatollah Kazim al-Heri now in Iran countered with a fatwa giving approval for Shi'a to fight on behalf of the Assad government. The recruitment networks for these fighters appear to be fairly informal. While informal networks of facilitators are involved in transporting housing and fighters once they arrive in Turkey the structure is not centrally administered. Jihadis often intend to fight with one organization and then find themselves associated with another once they are in Syria. As the Salafi Jihadists came to dominate the anti-Assad factions across the east of Syria both the native Syrian and foreign Salafi Sunni fighters were driven by the usual mix of political motivations to join a Jihad. In Syria however there is the additional subtext of the Sufyani narrative predicated on a claim of a Muslim tyrant arising in Damascus and ultimately being defeated by the Mahdi (an Islamic deliverer prophesized to defeat the enemies of Allah and rule for a period of years immediately before the Day of Judgment). While not a major stimulus it is relevant in actuating the desire of some young Jihadists to engage the fight against Bashar Assad as the archetype, if not the person, of that Sufyani (Islamic eschatology facilitates utilization of prophesy for politics whether there is a consensus among the scholar-jurists or not).

[42] Al Baghdadi was seriously injured in drone strike in early 2015 and designated Abu Alaa al-Afri as his successor in the event of al-Baghdadi's death. See "Isis leader incapacitated with suspected spinal injuries after air strike" The Guardian 1 May 2015. Al-Afri has himself been reported killed but the relevant point is that al-Baghdadi is arranging a succession.

[43] The IS is a new incarnation of al-Qaeda in Iraq (AQI) headed by Abu Musab al-Zarqawi until his death in 2006. Al-Baghdadi began building his organization anew in May of 2010. Some groups within ISIS are more cohesive fighting as distinct entities such as Abu Hanif's Jamaat made up primarily of fighters from Dagestan. The strength of ISIS is in the Anbar and Nineveh provinces of Iraq where it runs training camps. It also maintains a presence in Nineveh, Fallujah, and is now in control of Ramadi. Between 2012 and 2013 more than 600 Sunni militants escaped Iraqi prisons in a series of jailbreaks that buttressed the number of ISIS fighters. See “Anatomy of militant groups reveals Iraq's different challenges," The National UAE, 12 February 2014. See also "Escaped Inmates From Iraq Fuel Syrian Insurgency," New York Times, 12 February 2014.

[44] Michael Knight “ISIL's Political-Military Power in Iraq," CTC Sentinel, Volume 7, Issue 8, August 2014.

[45] "Self-funded and deep rooted: How ISIS makes its millions" CNN 7 October 2014, see also "ISIS making millions daily off crime, terror" CBS News 23 October 2014, and Yochi Dreazen "ISIS Uses Mafia Tactics to Fund Its Own Operations Without Help From Persian Gulf Donors” Foreign Policy 17 June 2014.

[46] Farhan Zahid and Mohammad Salman Foreign Analysis Number 1 “The Tehrek-e Taliban Pakistan In Syria" Centre Francais de Recherche Sur le Renseignement Paris 1 February, 2014.

[47] Salafi dervies from "Salaf al-Saleh" referring to the Righteous Companions of the Prophet and fall under the Hanbali school of jurisprudence. In the Syrian civil war the Sunni Ulema initially split with some like Grand Mufti Ahmad Hassan and Muhammad al-Bhuti supporting the Assad regime while Ulema in 


\section{Journal of Terrorism Research}

smaller cities were more sympathetic to the rebels. See "Syrian Baath Party and Sunni Islam: Conflict and Connivance," Middle East Brief 77, Crown Center of Middle East Studies Brandeis University, February 2014. [48] Nicholas A. Heras “The Struggle for Syria’s al-Hasakah Governorate: Kurds, the Islamic State and the IRGC” Terrorism Monitor Volume XIII Issue 7, 4 April 2015. The YPG is locally supported by an allied Sutoro militia made up of ethnic Assyrians. The frontier Kurdish city of Qamishli, sitting directly opposite Nusaybin Turkey, within Hasakah Governorate has the airport (along with the border crossing and a few neighborhoods) under Assad regime control with IRGC-Quds moving Iraqi Shi'a fighters from Najaf to the Qamishli airport to maintain a nominal Assad government presence.

[49] While the first iteration of ISIS then called the Islamic State in Iraq were characterized by quickly alienating local Sunnis the newer Islamic State appears to be a learning organization and appears to implement the rigors of Salafi tradition in a more staged manner.

[50] Christoph Reuter “The Terror Strategist: Secret Files Reveal the Structure of Islamic State" Spiegel Online International 18 April 2015.

[51] Ibid.

[52] The IS is generally following the process outlined in Abu Bakr Naji's treatise The Management of Savagery (Ida'rat al-Tawahhush).

[53] “The Islamic State's Baathist roots” Al Monitor 24 April 2015.

[54] A second weakness is that the IS is not an integrated army so much as it is a coalition of Islamist factions. The factions could hypothetically be targeted as distinct entities.

[55] “The Re-Bathification of Iraq" Foreign Policy 21 August 2014.

[56] "Military Skill and Terrorist Technique Fuel Success of ISIS," New York Times, 27 August 2014.

[57] Administration contains Sharia Courts, religious and local police, Sharia Institutes, Recruitment and Tribal Relations. Muslim Services apparently includes bakeries, water, and electricity.

[58] Charles C. Caris and Samuel Reynolds, "ISIS Governance In Syria," Middle East Security Report 22, Institute for the Study of War July 2014, 14 - 16. The Iraqi Shi'a Asa'ib al-Haq had an operational presence in Tal Afar in Nineveh Province which may have left a stay behind network as the IS took over.

[59] Dareed Gartenstein-Ross and Thomas Joscelyn, “Zawahiri's Revenge: Why al-Qaeda, not the Islamic State, is still the most dangerous terrorist organization on Earth," Foundation for the Defense of Democracies, July 31, 2014.

[60] “How Syria’s Assad Helped Forge ISIS” Newsweek 21 June 2014 See also “Assad regime set free extremists from prison to fire up trouble during peaceful uprising" The National 21 January 2014. Islamist prisoners were released from among the political prisoners Sednaya prison who later rose to the top of multiple Salafi Jihadist organizations including Hassan Abboud (Ahrar Al-Sham), Zahran Alloush (Jaysh al-Islam), and Ahmad `Aisa al-Shaykh (Suqour al-Sham).

[61] The Iraqi government previous attempts to seal the border against Sunni fighters moving into Syria met with mixed effect. For example at the Rabia-yaa Rabiya crossing one of the local tribal confederations the Shammar has many of its clans in Iraq and provides many of the fighters for the Free Jazira Brigade despite Baghdad's efforts. 


\section{Journal of Terrorism Research}

[62] Haian Dulhan, "Tribes and Tribalism in the Syrian Uprising," Syria Studies, Volume 6, Number 2 (2014), 18.

[63] Dareed Gartenstein-Ross and Thomas Joscelyn, "Zawahiri's Revenge: Why al-Qaeda, not the Islamic State, is still the most dangerous terrorist organization on Earth," Foundation for the Defense of Democracies, July 31, 2014.

[64] Thomas Joscelyn "Al-Qaeda jihadists celebrate release of anti-Islamic State Ideologue" Long War Journal 2 February 2015.

[65]Jabhat al-Nusra is said to have originated from al-Zarqawi's Syrian network of "guesthouses" for Jihadists transiting Syria to fight in Iraq following the American invasion. Bashar al-Assad had calculated it was to his political advantage to allow Syrian Jihadists to fight in Syria after the U.S. invasion in 2003. A Salafi cleric in Aleppo Abu al-Qaqaa coordinated with Zarqawi. Al-Nusra was formed between October of 2011 and January of 2012 as a result of meetings in Damascus and Homs. The organization mustered roughly 5000 fighters in 2012-2013 under Abu Mohammad al-Julani. Much of the core leadership apparently originated with Syrians who worked with Abu Musab al-Zarqawi in Herat Afghanistan. Zawahiri apparently planned the creation of specific cells in the al-Nusra organization tasked with identifying and recruiting Islamist fighters from European countries for future terrorist operations in Europe. See Norman Benotman and Roisin Blake, "Jabhat al-Nusra," Quilliam, 8 January, 2013.

[66]Waleed al-Rawi and Sterling Jensen, "Syria's Salafi networks More Local than you Think," PRISM A Journal of the Center for Complex Operations, Syria supplemental, Vol 4, 2014, 50 - 51.

[67] Directly west of Aleppo in Turkey's Hatay province U.S. interlocutors both in a Military Operations Center in Hatay city and in a U.S. facility in Reyhani on the border work with some pseudo-vetted rebel fighters such as Harakat Hazm (Movement of the Steadfast) and the Syrian Revolutionary Front although both were overwhelmed by Jabhat al-Nusra.

[68] This betrayal began with the 1920 Treaty of Sevres supposedly allowing for an independent Kurdistan and goes right up to 1975s when the Shah of Iran and the U.S. abandoned the Kurdish rebels fighting against Sadddam.

[69] "Qaraqosh Protection Committee" Wikipedia last updated 29 March 2015 and "Local Struggles in Syria's northeast" Washington Post, September 9, 2014. There is a larger Syriac Military Council operating in Hasakah under Gewargis Hanna.

[70] Ibid.

[71] It should be noted that smuggling and other criminal organizations are likewise actors in the conflicting alliance matrices.

[72] See "Research Summary Report: Local Truces in Syria" Integrity Research and Consultancy London June 2014.

[73] "The Last Bastion of the Syrian Revolt" ISN Swiss Federal Institute of Technology 17 February 2015. Also it was in Quarteira at Tel al-Hara the Russian Military Intelligence 6th Directorate Signals Intelligence Osnaz unit operated a regional listening post. See Carl Wege "Iran and Assad Are Not Winning" Fair Observer 1 April 2015.

[74] Aymen Jawad al-Tamimi 'The Druze Militias of Southern Syria” Middle East Forum 13 November 2013. http://www.meforum.org/3668/druze-militias-syria Accessed 10 May 2015. Hezbollah recently attempted 


\section{Journal of Terrorism Research}

to create a pro-government Druze "Lebayk Ya Salam" militia with little success. See "A Druze Conundrum: Suwayada, Jabhat al-Nusra, and the Syrian Civil War" Telaviv Notes Moshe Dayan Center, Volume 9, Number 8,26 April 2015.

[75] The Ramtha border crossing where Syria, Jordan and Israel meet was seized by the rebels in September of 2013. The north and east of Jordan is defended by the 2nd Royal Guard Mechanized brigade under the Jordanian Eastern Command. CENTCOM Forward Jordan (CF-J) also supports a Military Operations Center north of Amman that acts as a logistics and supply hub for approved rebel fighters.

[76] Aaron Lund has discussed the amorphous and ever changing nature of the Free Syrian Army idea. See Aaron Lund “The Free Syrian Armies: Institutional Split” Syria In Crisis Carnegie Endowment for International Peace 25 March 2014.

[77] See Jonathan Dupree, “Syria Update: The Southern Battlefronts," Syrian Assistance Blog, 6 April 2013.

[78] “Israel's Growing Role in Southern Syria," Policy Watch 2201, Washington Institute for Near East Policy, 29 January 2014.

[79] Bassam Barabandi and Tyler Jess Thompson "A Friend of my Father: Iran's Manipulation of Bashar alAssad” MENA Source Atlantic Council 28 August 2014 http://www.atlanticcouncil.org/blogs/menasource/afriend-of-my-father-iran-s-manipulation-of-bashar-al-assad Accessed 10 May 2015. See also "Eye of the Storm: The 'Iranization' of Syria" Jerusalem Post 1 November 2006.

[80] Khomeini's concept of Velayat-e Faqih was a departure from Iranian history where clerics had never ruled directly. See Azar Tabari,. "The Role of the Clergy in Modern Iranian Politics," in Religion And Politics In Iran. Nikki R. Keddie ed., New Haven and London: Yale University Press, 1983, 72. It is believed that Khomeini was inspired to this idea from the works of Jamal al-Din al-Afghani in the nineteenth century who called for an undefined revival of Islam along with Ali Shariati and Allama Iqbal.

[81] It is also worth noting that Iran had significant economic assets in Syria. Iran used Syrian development projects as a way to circumvent western economic sanctions in the 2000s. These development projects ranged from the Iranian Saipa Auto manufacturing plant to joint projects run by Bank Saderat Iran and the Commerical Bank of Syria. See Nadia von Maltzahn The Syria-Iran Axis: Cultural Diplomacy and International Relations in the Middle East I. B. Tauris:London, New York, et. al., Library of Modern Middle East Studies, 2013.

[82] "Al-Qaeda facilitator "back on the street" in Iran," Long War Journal 31 January 2014. These would include Ezedin Abdel Aziz Khalil (Yasin al-Suri), Mushin al-Fadhli and his deputy Adel Radi Saqr al-Wahabi al-Harbi. Al-Suri was then detained by the Iranian authorities and succeeded by al-Fadhl until recently when al-Suri was released and al-Fadhl moved to Syria to work with Jabhat al-Nusra. See also "Long War Journal Report: Former head of al-Qaeda network in Iran now operates in Syria," Long War Journal, March 25, 2014. See also Paul Hastert, “Al Qaeda and Iran: Friends or Foes, or Somewhere in Between?" Studies in Conflict and Terrorism, (30), 2007.

[83] Some have suggested this is an intentional effort on the part of Iran to make real the Damascus government narrative that Assad's opponents were Islamic terrorists rather than democratic reformers. In this view such an effort would also cause the West to cut off support for the rebels allowing Assad to win.

[84]Russian support of the Assad government is particularly relevant in keeps Assad's Air Force operational. See Christopher Kozak ““'An Army In All Corners” Assad’s Campaign Strategy In Syria” Middle East Security Report 26 Institute For The Study of War April 2015, 19. 


\section{Journal of Terrorism Research}

[85]Even western Syria is not immune from Sunni Jihadist infiltration however as thousands of foreign fighters including Libyans, Tunisians, and European Islamist fighters are crossing everywhere from Lebanon to Turkey. Some European Salafi sympathizers are going to Sidon, transiting to Ain al-Hilweh Palestinian camp and from there into Syria. "Syria's Saudi Jihadist Problem," The Daily Beast, December 16, 2013. The logistics of the arms flow supporting the rebels appears organized, in part, under the auspices of U.S. contractors managing funds supplied by Saudi Arabia and Qatar and using Syrian Ikhwan as interlocutors in Turkey. "Syrian opposition receiving arms through countries neighbors. Clans organize smuggling routes in Turkey, Iraq, Jordan and Lebanon." Jerusalem Post, July 18, 2012.

[86] "Inside the Octopus: Unraveling Iran's terrorist Quds Force," Israel Hayom, September 24, 2013. In 2012 when the armed revolt against Assad began to seriously threaten the regime in Damascus the Pasdaran in Syria was under the command of IRGC General Mohammed Reza Zahedi with General Ibrahim Jabri of the Revolutionary Guard's Lebanon Corps coordinating Iranian interests in Lebanon and protecting Iranian and Hezbollah assets in Syria proper.

[87] These included elements from the 14th Imam Sadegh Brigade and the 33rd al-Mahdi Brigade used in suppressing the "Green Movement" following Iran's contested 2009 elections and while the Basiji were given the more public role in repressing dissent in Iran they were operating under the administrative control of the Pasdaran. At the government to government level the major liaison between Bashar Assad and Tehran was Mohammed Nasif Kheirbek the one time head of GID internal security and later Special Assistant to President Assad for Intelligence and Security. It is problematic however at this point whether Kheirbek answers to Assad or Tehran. Will Fulton, Joseph Holliday and Sam Wyer, "Iranian Strategy In Syria," A Joint Report By AEI's Critical Threats Project and Institute For The Study Of War, May 2013, 11 and 15.

[88] This became more complicated in the early summer of 2014 as Iraqi Shia militia were also confronted with the need to protect the Shia populations in the south of Iraq.

[89] See “Syria Pro-Government Paramilitary Forces” The Carter Center 5 November 2013, p. 7.

[90] Jaysh al-Sha'bi were originally built on what were called Popular Committees (Lijan al-Sha'bia) that were reasonably spontaneous organizations of local militias who attempted to provide security in their own neighborhoods and were at first under the control of local notables and had no relation with the Shabiha thugs operated by the Assad's prior to the civil war. Country wide the NDF are now supposed to be organized in the various Syrian Governorates through a Governorate Security Committee nominally commanded by a retired Syrian Arab Army officer. The Assad government prefers to co-opt men who have completed their military service and can be re-trained quickly in one month courses in areas of the various Governorates still controlled by the regime.

[91] Aaron Lund “The Baath Battalions Move into Damascus" Carnegie Endowment for International Peace 13 January 2014.

[92] Latakia airport is seeing major Iranian funded expansion as an alternative to Damascus international airport should that eventually fall to the rebellion. Tartus by contrast is an ethnically mixed city now filled with Sunni and Christian regime supporters who are refugees from Homs, Aleppo, and even Damascus.

[93] Nicholas A. Heras, “The Potential For An Assad Statelet In Syria," The Washington Institute For Near East Policy, Policy Focus 132, December 2013, 19.

[94] Aron Lund, “The Baath Battalions Move Into Damascus," Syria In Crisis, Carnegie Endowment for International Peace, 13 January, 2014. 


\section{Journal of Terrorism Research}

[95] Nasrallah has publically stated that the fall of Assad would lead to the decline of Hezbollah. See

"Nasrallah: Downfall of Assad would mean fall of Hezbollah" The Jerusalem Post 8 May 2015.

[96] Examples of these smaller militias include Iraq's Badr Organization posting about 1500 fighters in Damascus, the Sarriya al-Talia al-Khurasani under Sayyed Ali al-Yasseri with 600 fighters tasked by Iran's Revolutionary Guards to protect the Damascus airport. http://revoultionsyria.blogspot.com/2014/06/shiitemilitias-in-syria.html Accessed 9 May 2015.

[97] Christopher Anzalone “Zaynab’s Guardians: The Emergence Of Shi’a Militias In Syria” CTC Sentinel Combating Terrorism Center 23 July 2013.

[98] Nicholas Heras “A Shadow of Iraq’s Sectarian War in Damascus' Suburbs” Fair Observer 24 October 2012.

[99] Hezbollah of late has apparently been facilitating European mercenaries recruited through M Security Group to fight on behalf of the Assad regime. The mercenaries appear to be recruited in Eastern Europe and flown to Rafik Hariri airport in Beirut and transferred to the Damascus area. The numbers appear relatively small and it is likely funded via Iran perhaps with Russian acquiescence. However the resources necessary to manage the logistics of such and endeavor indicate the effort is not merely incidental but has some intentionality.

[100] With hundreds dead the Hezbollah deployment into Syria is not without controversy. Sheikh Subhi Tufalyi a founding member who left the organization in the late 1990s has articulated those doubts and the financial cost of the Syrian war is likewise bleeding Iran and Hezbollah white. Hezbollah has been forced to create two war councils, one for Lebanon and one for Syria to manage the spillover from Syria in addition to the historic Jihad Council Hezbollah has had since the early 1990s.

[101] Kozak ““'An Army In All Corners” Assad’s Campaign Strategy In Syria” Institute For The Study of War April 2015, p. 28. The configuration of Hezbollah's pre civil war Syrian logistics train was anchored in units 100, 108, and 112. Unit 100 managed the particulars of transferring both Hezbollah fighters and Iranian advisors between Lebanon, Syria, and Iran. Hezbollah Unit 108 managed weapons transfers from storage areas in Syria to Lebanon. Weapons storage facilities in Adra near the Damascus International Airport and in Duma were under administrative Unit 108 control. Unit 108 also maintained reserve storage sites in Tartus and in both the Aleppo and Homes regions. Once in Lebanon Unit 112 dispersed the arms to logistics centers in the Bekka. See "In secret caches of weapons of Hezbollah" Le Figaro 25 October 2010

[102] Jeffrey White "Hizb Allah at War In Syria: Forces, Operations, Effects and Implications" CTC Sentinel Combating Terrorism Center 15 January 2014.

[103] "Iran dials Up Presence in Syria," Online Wall Street Journal, 16 September, 2013. Hezbollah is also using the ruins of the town as a facility for urban warfare training.

[104] Carl Wege “Syria’s Loyalist Archipelago” Fair Observer 7 May 2013.

[105] Kozak ““'An Army In All Corners” Assad’s Campaign Strategy In Syria” Institute For The Study of War April 2015, p. 27.

[106] Hezbollah had actually signed a document called the Baabda Declaration in 2012 with other Lebanese parties pledging non-interference in Syria.

[107] The Syrian war is stimulating the growth of the Hezbollah infrastructure as well. It has been reported, for example, that Hezbollah built an airfield about seven miles west northwest of Baalbek from which it flew 


\section{Journal of Terrorism Research}

Mohajer (sometimes called Mesad) drones. Although these are technologically antiquated it does illustrate Hezbollah's evolution into a semi-conventional military force. See "Hezbollah built an airport, secret tunnels near Baalbek," YaLibnan, 4 March, 2014.

[108] Prior to the Syrian civil war Hezbollah had a thirty year development curve while the Iraqi Shi'a militia have a much more limited development history and less organizational coherence.

[109] "Iran dials Up Presence in Syria," Online Wall Street Journal, 16 September, 2013. Iran is attempting to quick train these Iraqi Shi'a in short courses are reported conducted as 15 or 45 day cycles incorporating the usual low intensity operations training provided in terrorist training camps. The training venues appear to include Sanandaj and Varamin, as well as at the al-Momenin ballistic missile facility.

[110] The al-Abbas Brigade sent a symbolic contingent of fighters to deploy south of Baghdad in solidarity with Iraq's Shi'a now threatened by the Islamic State.

[111] The majority of those organizations developed from the Badr Corps later Badr Organization in coordination with the Revolutionary Guards Ramazan Corps. The Badr Organization currently has direct ties to Iraq's Internal Security Forces and Badr veterans populate Kata'ib Hezbollah and other Shi'a militias. Badr has also created a militia called Martyr Baqir al-Sadr now deployed in Syria. Fadl al-Abbas alludes to a warrior martyred while supporting Imam Husayn at Karbala.

[112] Qais al-Khazah now also claims a political wing called al-Sadigun (Honest Ones).

[113] These organizations both sometimes fight under a combined name of the Abu al-Fadl Al-Abbas Brigade under Abu Ajeeb. See Michal Harqi, “Status Update: Shi'a Militia's in Iraq" Institute for the Study of War, August 16, 2010. The Abu Fadl al-Abbas Brigade is part of the Kata'ib Hezbollah. There are more than a dozen identifiable Iraqi Shi'a factions now fighting in Syria with several thousand Iraqi Shi'a fighters in Syria. These factions are sometimes splinters from existing groups Kata'ib Sayyid al-Shuhada under Abu Mustafa al-Sheibani for example is little more than a group from Kata'ib Hezbollah operating in Damascus.

[114] "Abu Mahdi and Iran's Web in Iraq," United Press International, October 7, 2010. Iran's interests may be served by these Shia affiliated auxiliaries coalescing into a coherently organized and centrally commanded military network managed under the auspices of the IRGC supporting Tehran's interests in a Shi'a allied Syrian rump state in western Syria. These designations are somewhat ambiguous because frequently the militias adopt local monikers defined by geographic area for example, Kata'ib Hezbollah fighters located in southern Damascus appear to operate under the name of Kata'ib al-Shuhada. See Phillip Smyth, "Hizballah Cavalcade: Kata'ib Sayyid al-Shuhada: Another Supplier of Iraqi Shia Fighters in Syria," Jihadology, June 3, 2013.

[115] Lebanon's Hezbollah through the efforts of Ali Mussa Daqduq directly guided the formation of the organization in Iraq as it splintered from Moqtada al-Sadr's Mahdi Army (Jaysh al-Mahti). Sam Wyer notes that Asa'ib al-Haq probably operates a jihad council similar to that of Hezbollah and has divided its militia operations in Iraq into functional "battalions" organized along regional lines. See Sam Wyer "The Resurgence of Asa'ib Altl Al-Haq," Middle East Security Report 7, Institute for the Study of War, December 2012, 13. What is likely operating in Syria is a specialized element of the organization now called Liwa Kafil Zaynab See also See Smyth "From Karbala to Sayyida Zaynab: Iraqi Fighters in Syria’s Shia Militias," CTC Sentinel Vol 6 Issue 8, August 2013. In 2014 Asa'ib al-Haq also deployed in Iraqi Anbar to confront the Islamic State. Parallel to that confrontation a splinter organization of Asa'ib al-Haq called Harakat Hezbollah al-Nujaba is kinetically engaging the Kurds because of their alliance with the United States and other Western powers. 
[116] "Iraqi Shiites join Syria War, AL-Monitor, 29 October 2013. Asa'ib al-Haq coordinates some activities through a Asa'ib al-Haq Center for Studies in Beirut funded through Afif Nabulsi with Sheikh Ammar alDelphi liaising with Lebanon's Hezbollah.

[117] Stephen Wicken, "New War, Old Faces," The Majalla, 23 April 2014.

[118] See http://revoultionsyria.blogspot.com/2014/06/shiite-militias-in-syria.html Accessed 9 May 2015.

[119] The Tripoli based Sheikh Hussam al-Sabbagh for example appears to be acting as a Lebanese representative for Jabhat al-Nusra. The Taamir quarter in Ain al-Hilweh Palestinian camps is becoming a nexus for Abdullah Azzam Brigade fighters and appears to have operatives from both al-Nusra and ISIS present.

[120] "The Threat of the "Salafi Crescent," Arutz Sheva, January 23, 2014. The Sunni Alfawwara, Turki, and Bani Khaled clans on the Lebanese side have been particularly active. See also "Free Syrian Army gets tribal support in areas bordering Turkey, Iraq," BBC Worldwide Monitoring Service, June 21, 2012.

[121] This corresponds in some ways to what happened across Syria where Salafi radicalization was initially more prominent in rural areas and secondarily in urban areas.

[122]Isabel Nassief, "Hezbollah And The Fight For Control In Qalamoun," Institute for the Study of War, November 26, 2013. Majid al Majid the Saudi born leader of the Azzam Brigade was arrested in the Yarze area of Beirut and died in Lebanese army custody in January 2014.

[123] “Tripoli Clashes: Keeping Conflict Alive” Alakhbar English 14 February 2012. Tripoli is home to most of Lebanon's 90,000 or so Alawites settled in the suburban Jabal Mohsen area along with scattered Alawite villages in the northern Akkar region. It is also worth noting that for many, perhaps most, Alawites their identification as Alawi is cultural more than religious. Unlike many Salafi Jihadists whose religiosity is quite real many Alawites appear analogous to secular Jews with self-identification anchored in culture and kinship more than actual religious faith

[124] These were precipitated in part by Salafi preachers like Sheikh Ammad al-Assir known for personally mobilizing a militia he called the Kata'ib al-Muqawama al-Hurr to fight in Syria "Lebanese Salafist Cleric Organizes Militia Forays into Syria," Terrorism Monitor, Vol II, Number 10, 17 May, 2013.

[125] Lucas Winter “Al-Qaeda’s Road To Damascus? Syria and the Abdullah Azzam Brigades” Foreign Military Studies Office Leavenworth 2012.

[126] Robert Rabil “Salafism in Lebanon” The Washington Institute Policywatch 2375, 20 February 2015.

[127] Peter Newmann “Suspects into Collaborators" London Review of Books Volume 36 (7), 3 April, 2014.

[128] Aram Nerguizian "Lebanon At The Crossroads" Statement before the U.S. Senate Foreign Relations Subcommittee on Near Eastern and South and Central Asian Affairs 25 February 2014.

[129] The integration of the Syrian and Lebanese economies has been discussed the Washington Institute's Andrew Tabler. See Andrew Tabler "The economic relationship: Beyond all political fallout the economies of Syria and Lebanon remain deeply intertwined and complementary" Executive Magazine April 2005, Number 70.

[130] Major Casey Mills, U.S. Army “S3 - Scale, Scope, Salience: A New Model for Evaluating Terrorist Threats" Special Warfare October - December 2014, Volume 27, Issue 4, 14. 


\section{Journal of Terrorism Research}

[131] John L. Esposito and John Obert Voll Islam and Democracy Oxford University Press: New York, Oxford, et. al. 1996, 180.

[132] Kenneth M. Pollack A Path Out of the Desert: A Grand Strategy for America In The Middle East Random House Trade Paperback: New York, 2008, 150.

[133] Richard Barrett “Foreign fighters in Syria” The Soufan Group June 2014, 6.

[134] Consequently Turks, Qataris, and Saudis hear different things from the same people.

[135] Aaron Lund, “Gangs of Latakia: The Militiafication of the Assad Regime," Syria Comment, 23 July, 2013.

\section{Bibliography}

Al-Rawi, Waleed and Sterling Jensen "Syria's Salafi Networks more local than you think" PRISM A Journal of the Center for complex Operations Syria supplemental Vol 4, 2014: 43 - 57.

Barrett, Richard "Foreign fighters in Syria” The Soufan Group June 2014: 1- 34.

Benotman, Norman and Roisin Blake, “Jabhat al-Nusra” Quilliam, 8 January 2013.

Caris, Charle C.and Samuel Reynolds, "ISIS Governance In Syria," Middle East Security Report 22 Institute for the Study of War July 2014.

Crenshaw, Martha, "An Organizational Approach To The Analysis Of Political Terrorism," Orbis 29 (Fall 1985): 465-489.

Davies, James C., “Toward a Theory of Revolution,” American Sociological Review, 1962, 27(1): 5-19.

DeChatel, Francesca, “The Role of Drought and Climate Change in the Syrian Uprising: Untangling the Triggers of the Revolution," Middle Eastern Studies Volume 50, Number 4: 521 - 535.

Donker, Teije Hiddle, “enduring Ambiguity: Sunni Community - Syrian Regime Dynamics," Mediterranean Politics Volume 15, Number 3 (November 2010): 435 - 452. Dulhan, Haian, "Tribes and Tribalism in the Syrian Uprising," Syria Studies Volume 6, Number 2 (2014): 1 - 28.

Esposito, John L. and John Obert Voll. Islam and Democracy Oxford University Press: New York, Oxford, et. al. 1996.

Faksh,, Mahmude A. “The Alawi Community of Syria: A New Dominant Political Force,"Middle Eastern Studies 20, no. 2 (April 1984): 133-135.

Fullton, Will, Joseph Holliday and Sam Wyer Iranian Strategy In Syria, A Joint Report By AEI's Critical Threats Project and Institute For The Study Of War May 2013.

Hastert, Paul “Al Qaeda and Iran: Friends or Foes, or Somewhere in Between?" Studies in Conflict and Terrorism, 2007, (30): 327 - 336.

Heras, Nicholas A., The Potential For An Assad Statelet In Syria The Washington Institute For Near East Policy, Policy Focus 132, December 2013.

Hokayem Emile. Syria's Uprising and the Fracturing of the Levant Adelphi Books 2013.

Kilcullen, David and Nate Rosenblatt “The Rise of Syria's Urban Poor: Why the War for Syria's Future Will Be Fought Over the Country's New Urban Villages” PRISM Syria Supplemental Center for Complex Operations Volume 4, 2014: 33 - 41. 


\section{Journal of Terrorism Research}

Kozak, Christopher ““'An Army In All Corners” Assad’s Campaign Strategy In Syria” Middle East Security Report 26 Institute For The Study of War April 2015.

Lawson, Fred H., Global Security Watch: Syria Santa Barbara California, Denver Colorado, and Oxford England: Praeger Press, 2013.

Leenders, Reinoud, “Social Movement Theory And The Popular Uprising In Syria," Arab Studies Quarterly, Volume 35, Number 3: 273-284.

Leenders, Reinoud and Steven Heydemann "Popular Mobilization in Syria: Opportunity and Threat, and the Social Networks of the Early Risers," Mediterranean Politics, Volume 17 (2): 139-159.

Pierret, Thomas, Religion and State in Syria: The Sunni Ulama from Coup to Revolution, Cambridge, New York, Melbourne, Madrid, Cape Town, Singapore, Sao Paulo, Delhi, Mexico City: Oxford University Press, 2013.

Pollack, Kenneth M. A Path Out of the Desert: A Grand Strategy for America In The Middle East Random House Trade Paperback: New York, 2008.

Schaebler, Birgit, "Constructing Identity between Arabism and Islam: The Druzes in Syria" The Muslim World, Volume 103, Number 1, (January 2013): 62 - 79.

Tabari, Azar. “The Role of the Clergy in Modern Iranian Politics” in Religion And Politics In Iran. Nikki R. Keddie ed., New Haven and London: Yale University Press, 1983.

Von Maltzahn, Nadia The Syria-Iran Axis: Cultural Diplomacy and International Relations in the Middle East I. B. Tauris:London, New York, et. al., Library of Modern Middle East Studies, 2013

Zelin, Anon, “The Saudi Foreign Fighter Presence in Syria,” CTC Sentinel April 2014: 10 - 14. 